\title{
NETWORKING IN A TRANSNATIONAL COOPERATION SPACE-THE CASE OF THE ODER PARTNERSHIP
}

\author{
ALEXANDER TÖLLE \\ Institute of Socio-Economic Geography and Spatial Management \\ Adam Mickiewicz University \\ Dzięgielowa 27, 61-680 Poznań, Poland \\ e-mail: atoelle@amu.edu.pl
}

\begin{abstract}
The globalisation of economic relations in conjunction with the European integration process has resulted in the creation of strategic networks between cities and regions on a transnational level. The overall motivation is to combine strengths and to balance weaknesses in order to compete with other spaces. In this context, the Polish-German "Oder Partnership" created in 2006 between four voivodships and four federal states including Berlin may be interpreted as a transborder strategy to foster economic development in from a European perspective deprived regions. A look on its first steps shows the potentials of the network tool as well as obstacles on the long way to the creation of stable cooperation structures.
\end{abstract}

Key words: Strategic networks, cooperation space, transnational cooperation, European regions, Polish-German cross-border cooperation, Oder Partnership

\section{INTRODUCTION: STRATEGIC NETWORKING BETWEEN EUROPEAN REGIONS}

The globalisation of economic relations has led to a profound restructuring process of spatial relations. Cities and regions find themselves in a net of global flows (Castells 1989), and integration into that net becomes more important for their prosperous development than national policies. With business relations becoming more and more integrated into transnational networks (Stryjakiewicz 2008) the same is required of cities and regions, as they are forced to open up to the extended markets by an internationalisation of their infrastructure and institutions. In Europe one may assert a "double internationalisation" (Kujath and von Schlippenbach 2002) as the globalisation process is intertwined with the European integration process 
shifting political power from the Member States to the institutions of the European Union. This integration process has been characterised right from its early beginnings by regionalisation tendencies, with regions being today the main theatre for European structural policies and public responsiveness in daily life. The vision of the "Europe of Regions" included also cross-border regions, and cross-border, transnational, and interregional cooperation was supported notably since 1991 by the INTERREG funds. These processes resulted in the creation of countless strategic networks between European cities and regions on a transnational level.

The general appeal of networking lies in its ability to combine strengths and to balance weaknesses in order to compete with other regions (Knieling and Kunzmann 2005). At the essence of any network is its actor-centred basis: the network's nodes are always social actors, be it individual human beings, groups, organisations or institutions. These actors are operating, as Fürst (2005) has summoned, via personal contacts, confidence, rules of fairness and reciprocity, and social norms. In contrast to cooperation structures that create a "social system" in order to achieve defined targets, network structures are rather a "social infrastructure" enabling to get to know partners, thus creating a "creative space" offering opportunities and contacts (Payer 2008). Strategic networks are characterised by loose relationships between the participating partners, and even their number may not be specified. The informal and non-binding character makes networks difficult to steer and it takes a longer time span to produce results. Yet there are also decisive positive points of networks: Each partner expects to benefit through participation in it (benefit-orientation), and this benefit is to be a product of the fact that each partner brings in his relevant capabilities or resources (reciprocity). The surplus value of networking is to result from the adding up of individual strengths (strengths-orientation), yet as no partner is expected to bring in more than his relevant strength, he is not at risk as a whole in the case that anything goes wrong. i.e. he keeps his full autonomy (partial interconnectivity). Due to these four characteristics networks have become of special interest as an informal tool in order to address common development tasks in particular under conditions in which no agreed or routine procedures are existing (Morgan et al. 2000; Fürst 2005).

Hence a strategic network may serve to define common interests and objectives as well as to get to know partners and to create confidence. In this way it may lead to the creation of cooperation structures concerning specific projects. Yet a network may also have a special function in a cooperation space in that it may integrate different cooperation structures on different levels into a broader context as "meta cooperation". There are numerous examples in Europe-e.g. the "Greater Region SaarLorLux", the Oresund Region, or the emerging "Central European Region CENTROPE"- how transnational networks have become institutionalised, thus leading to the emergence of functional cross-border regions. In such regions, networking on specified action fields has led to common spatial and socioeconomic development policies, usually with a strong connection to EU funding objectives. 
The action fields of transnational strategic networks in European cooperation areas may be summarised in the tasks of enhancing economic cooperation, especially between SME, lobbying on the European and the respective national level, implementing "hard" projects notably in the field of infrastructure and transport connections in the cooperation area, exchanging best practice experiences notably in the sense of "learning networks", and elaborating transnational marketing and tourism strategies (Kujath and von Schlippenbach 2002; Knieling and Kunzmann 2005; Antalovsky 2006; MOT 2006). It appears to be clear, that the Oder Partnership that will be discussed in this article is to define its objectives within the range of these action fields, and that, while it may be in its present early stage a network rather in the sense of a "creative space", it will have to aspire to create a network in the sense of a "meta cooperation" for a European macro cooperation space.

\section{THE EMERGENCE OF A POLISH-GERMAN MACRO COOPERATION SPACE}

Genuine cross-border contacts and cooperation between Poland and Germany have been next to non-existent for four decades after the Second World War. So, in this respect, it is justified to speak of a "zero hour" when referring to the fall of the IronCurtain in 1989. Forms of cross-border cooperation developed during the early 1990s notably in the four created Euroregions of Pomerania, Pro Europa Viadrina, Spree-Neisse-Bobr and Neisse, and in the so-called "laboratories of European integration", i.e. the "twin cities" on Oder and Neisse divided by the river border. However there was no shift towards a broader perspective of cross-border cooperation during the 1990s, even though there existed since 1995 the "Spatial Leitbild for the German-Polish Border Area", a product elaborated by the joint German-Polish Ministerial Commission for Spatial Planning. The defined objectives-diminishment of separating effects, diminishment of socioeconomic differences particularly concerning quality of life, consolidation of functionality and competitiveness of the major economic development centres on both sides-were never turned into active policies. So the "Actualisation of the Spatial Leitbild for the German-Polish Border Area" document approved in 2002 fell short of being an update based on the analyses of its predecessor (Ciok et al. 2008) and stays in line with its general directions. A remarkable change however is the enlargement of what is defined as the border area: the initial area (roughly the territories covered by INTERREG A) including Szczecin as the only large urban agglomeration has become the "closer border area", while the "border area" extends to the cities of Poznan, Wrocław, Dresden and Berlin. This definition was the basis for an initiative in the same year by the Polish-German Planning Commission to create a transnational economic space in the pentagonal area between the said five cities under the title of "The German-Polish House". While this initiative in itself also failed to get political support, it appeared to have set the ground for a new thinking. 
This change was stimulated by different factors. The first concerned the Polish side, where the reform of the country's territorial division in 1999 had created a regional level of 16 voivodships. This meant an extension of territorial self-government to the regional level, including notably the possibility to get engaged into transnational cooperation (Kaczmarek 2006). In that the German federal states ("Länder") were given Polish counterparts, even though the latter's constitutional condition is in comparison somewhat weaker: as voivodships are both central government and regional units, they are more dependent upon national policies and decisions than the German federal states, especially in financial and legal questions. The second change came with the process of shaping a territorial concept for the European Union. This resulted in the European Spatial Development Perspective ESDP (signed in 1999 by the then $15 \mathrm{EU}$ member countries) and its follow-up document, the Territorial Agenda of the European Union TAEU (signed in 2007 by all 27 Member States). The members agreed on the objectives of territorial cohesion and polycentric development, objectives to be reached notably by the means of territorial cooperation (Dühr et al. 2007). The two targets of achieving a balanced development of all regions in the EU and of strengthening global competitiveness the EU territory as a whole converge in the strategy to foster the development of metropolitan regions in order to achieve a better integration into global market structures-notably of those situated outside the EU core area defined in the ESDP. Extended forms of cooperation between regional and local authorities-as the new "key actors" (Ahlke et al. 1999) - is seen as the vital tool for the implementation of the EU spatial development concept. In that, the aspect of cross-border as well as of transnational cooperation is gaining increasing importance, as is the aspect of "learning" in such structures. Consequently, in the present programme period 2007-2013 territorial cooperation has become an objective in its own right.

All these factors are to be seen in the context of a steadily progressing process of European integration in the Polish-German border area, with the key events being the Polish accession to the EU in 2004 and to the Schengen zone in 2007. The political debate on a transnational cooperation in a Polish-German macro space started in the course of a state visit of the then Polish president to Germany in 1999 who developed the vision of an "Oder Community of Science, Technology and Economy" (Kohlisch 2008). It took however seven years of preparatory talks on different levels before the idea gained momentum. In 2006, the Berlin Senate for Economics organised the "Conference on economic cooperation in the Oder region", in which met major political and administrative representatives of the German federal states of Berlin, Brandenburg and Mecklenburg-Cispomerania (Mecklenburg-Vorpommern), of the voivodships of Lower Silesia (Dolnośląskie), Lubusz (Lubuskie), Greater Poland (Wielkopolskie) and West Pomerania (Zachodniopomorskie), and of the latter's capital cities of Wrocław, Gorzów Wielkopolski and Zielona Góra, Poznań, and Szczecin. In the final communiqué as the founding document for the "Oder Partnership", the political representatives agreed to continue 
their cooperation on a permanent basis in order to develop the macro-region formed by their territories into an "innovative, knowledge-based economic area", able to compete with other European regions. Cooperation-also with special regard to European structural funds-is to be focused on three sectors: firstly innovation, technology and small and medium-sized enterprises, secondly tourism, and thirdly transport and logistics, notably improvements of cross-border connections. The basis for cooperation was the network established in the preparation of the conference, which was to be coordinated by the Berlin Senate and-as agreed one year later-by the West Pomeranian voivodship for the Polish side. The Berlin conference was continued by annual political meetings that took place in 2007 in Szczecin and in 2008 in Poznań. The latter had a special meaning in two respects: firstly it involved also high-level representatives of the federal state of Saxony (Sachsen), which meant that Saxony started to get involved in the Partnership. Secondly it was attended by officials from the Polish as well as the German foreign office, which meant the integration of the Oder Partnership into the context of national foreign policy. The Oder Partnership may therefore be seen to have a stable political frame as its basis (Figure 1).

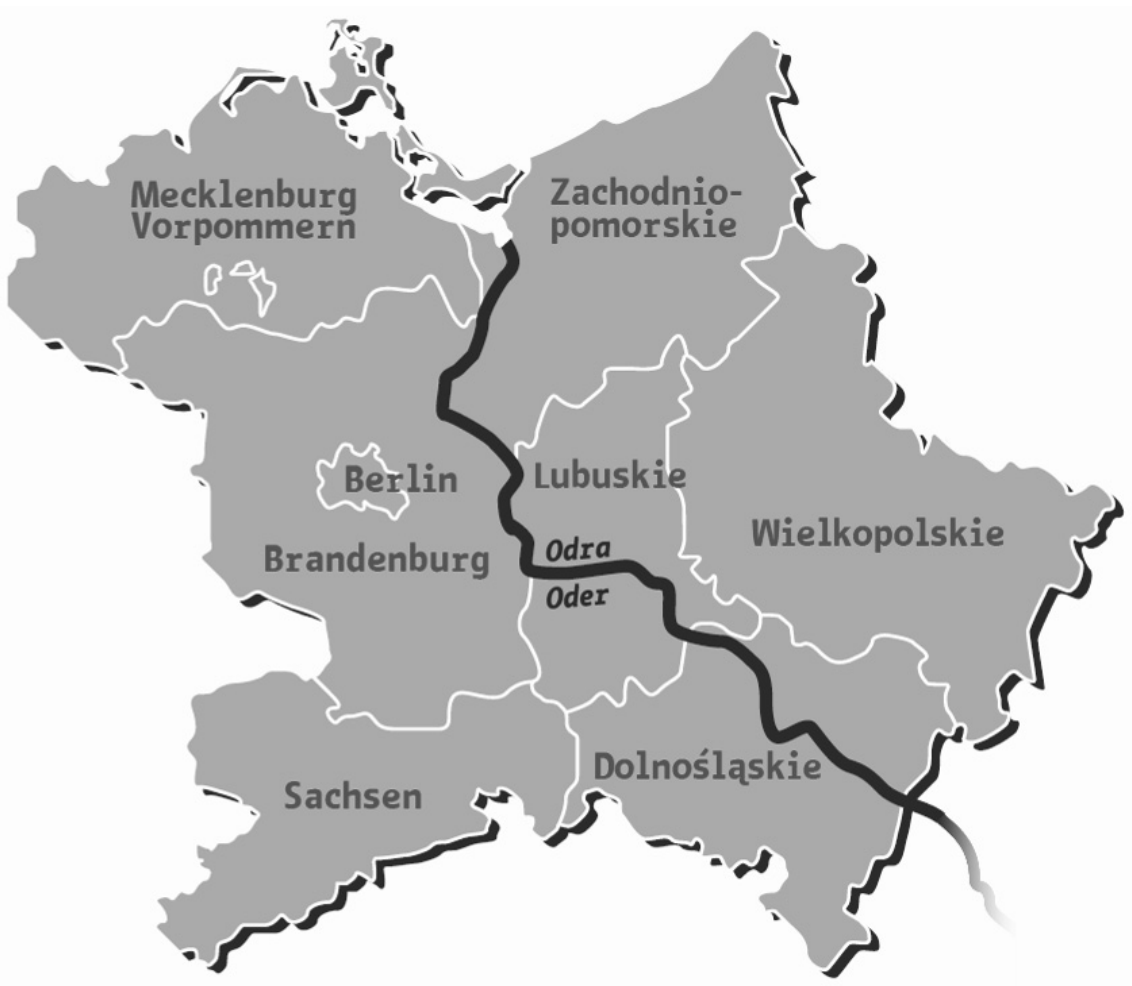

Figure 1. Polish and German regions in Oder Partnership Source: <http://www.oder-partnerschaft.eu/>. 


\section{TERRITORIAL STRUCTURE OF THE PARTNER REGIONS}

The Oder Partnership is consisting of regions that represent quite different socioeconomic and spatial structures. While the regions of Berlin-Brandenburg, Saxony, Greater Poland and Lower Silesia are consisting to a large extend of urban agglomerations, Lubusz, West Pomerania and Mecklenburg-Cispomerania are predominantly characterised by a rural structure with small and medium-sized towns, the latter region has even the lowest population density of all German federal states (Table 1).

Table 1. The partners in the Oder Partnership

\begin{tabular}{|c|c|c|c|c|c|c|c|c|c|c|}
\hline & 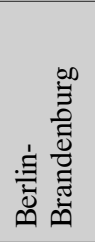 & 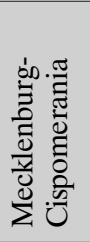 & $\begin{array}{l}\overrightarrow{0} \\
\text { त् } \\
\text { 心 }\end{array}$ & 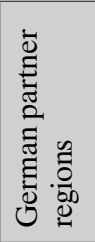 & 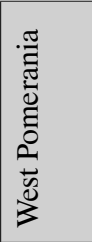 & 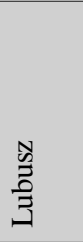 & 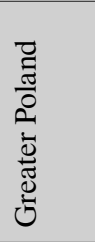 & $\begin{array}{l}\frac{\pi}{5} \\
\frac{0}{5} \\
5 \\
\dot{0} \\
0 \\
0 \\
\end{array}$ & 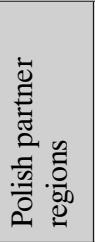 & 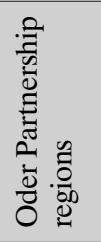 \\
\hline $\begin{array}{l}\text { Territory in } \\
\text { thousand } \mathrm{km}^{2}\end{array}$ & 30.37 & 23.19 & 18.42 & 71.98 & 22.89 & 13.99 & 29.83 & 19.95 & 86.66 & 158.64 \\
\hline $\begin{array}{l}\text { Population in mil- } \\
\text { lion inhabitants }\end{array}$ & 5.96 & 1.68 & 4.22 & 11.86 & 1.69 & 1.01 & 3.39 & 2.88 & 8.97 & 20.83 \\
\hline $\begin{array}{l}\text { Inhabitants } \\
\text { per km² }\end{array}$ & 196.2 & 72.5 & 229.1 & 164.8 & 73.8 & 72.2 & 113.6 & 144.4 & 103.5 & 131.3 \\
\hline
\end{tabular}

Source: For Germany Federal Statistic Office Wiesbaden, for Poland Main Statistic Office Warsaw, 2007.

These figures however do not reveal the existing disparities within the regions. On the German side, it must be emphasised first that the German Capital Region of Berlin-Brandenburg consists actually of two independent federal states: the city state of Berlin and the surrounding state of Brandenburg with its capital city of Potsdam (ca. 150,000 inhabitants). Nevertheless both states understand themselves as a common metropolitan region. There is close cooperation on numerous fields, and notably concerning spatial development. Planning documents are elaborated by the Joint Division of Planning, a body consisting of administrative staff from both federal states. To that adds the realisation of joint major projects, e.g. the new airport of "Berlin Brandenburg International". While the whole territory of Brandenburg is seen as belonging to the Capital Region there are nevertheless significant disparities. The inner area around Berlin—notably the southwest including Potsdam—is characterised by high population density and socioeconomic growth processes, while the other larger cities such as Cottbus (ca. 103,000 inhabitants), Brandenburg-upon-Havel (ca. 73,000 inhabitants) and Frankfurt-upon-Oder (ca. 62,000 inhabitants) are struggling with massive job and population losses, just as the remaining areas are characterised by a low population density and predominant rural functions. The latter characteristics are also typical for the federal state of Mecklenburg-Cispomerania with its rural structure, the only larger urban centres being the Baltic port city of Rostock 
(ca. 200,000 inhabitants) and the state's capital Schwerin (ca. 95,000 inhabitants). The socioeconomic structure is however characterised by a strong internal differences, with the situation in south-eastern areas, including the borderland to Poland, being far more dramatic than in northern (along the Baltic coastline) and western (close to the booming Hamburg Metropolitan Region) areas. The Free State of Saxony in turn is traditionally one of the most industrialised and urbanised areas of Germany. Its biggest agglomerations are the state's capital of Dresden (508,000 inhabitants), Leipzig (ca. 511,000 inhabitants), and the urban agglomeration of Chemnitz (244,000 inhabitants) and Zwickau (95,000 inhabitants). Since spring 2009, the three agglomerations have become part of a strategic partnership called the "Metropolitan Region of Central Germany" (Metropolregion Mitteldeutschland), including also three cities outside Saxony. This is to be seen as an ambitious initiative on city government level to foster networking between research, scientific and economic institutions. Apart from the urban centres Saxony has also structurally weak rural areas in its northern parts as well as booming tourism destinations in its mountainous southern parts.

On the Polish side the voivodships of West Pomerania and Lubusz appear to reflect to certain extend the situation in Mecklenburg-Cispomerania and in the more peripheral parts of Brandenburg. West Pomerania is characterised by a rural structure with small and medium-sized towns, the only larger urban centres being the voivodship's capital Szczecin (407,000 inhabitants), Koszalin (107,000 inhabitants) and Stargard Szczeciński (ca. 70,000 inhabitants). The Lubusz voivodship in turn is characterised by a rural structure with small and medium-sized towns and has-in contrast to the other regions in the Oder Partnership-no metropolitan centre. Its only two larger urban centres are sharing the capital function, with Gorzów Wielkopolski (125,000 inhabitants) being the seat of the central government voivode office and Zielona Góra (117,000 inhabitants) being the seat of the region's elected government. Quite different is the territorial structure in the massively urbanised voivodships of Lower Silesia and Greater Poland. The latter's territory comprises of the land of the historic "cradle" of Polish statehood and Christianity. From the four voivodships in the Oder Partnership it is the only one whose territory has been part of inter-war Poland, and the only one that has no border with Germany. The region's centre is the voivodship's capital city of Poznan (567,000 inhabitants), the other urban centres include Kalisz (108,000 inhabitants), Konin (81,000 inhabitants), and Gniezno (69,000 inhabitants). It is the third most densely populated voivodship in Poland. Lower Silesia in turn is one of Poland's most industrialised regions with its main urban centres being its capital city of Wrocław $(633,000$ inhabitants) and the cities of Wałbrzych (124,000 inhabitants), Legnica (105,000 inhabitants), and Jelenia Góra (86,000 inhabitants). The Giant and Sudetes Mountains in the southwest part of the voivodship are among the most important Polish tourist regions.

The territory of the Oder Partnership is fairly equal divided between Germany (45.4\% of land) and Poland (54.6\%), as are population figures (with $56.9 \%$ of inhabitants living in the German and $43.1 \%$ in the Polish regions). What is however 
striking is the sheer size of the cooperation area of $158,640 \mathrm{~km}^{2}$, which is significantly more than other macro cooperation spaces in Europe have (e.g. the Greater Region SaarLorLux with $65,400 \mathrm{~km}^{2}$ or the CENTROPE region with $44,221 \mathrm{~km}^{2}$ ). It has been proven before that cross-border cooperation in large cooperation areas is significantly more difficult due to a lower degree of commitment, higher transaction costs and reduced communication on a personal level (Knippschild 2008), so this may pose a problem if cooperation is to be extended beyond the five easy-accessible metropolitan centres.

\section{SOCIOECONOMIC PARAMETERS OF THE ODER PARTNERSHIP REGIONS}

When looking at the socioeconomic parameters of the partner regions one needs to distinguish between the respective national, the Polish-German, and the European perspective. The German partner regions including the Capital region are all to be characterised as rather poor on the national level. Their share in the national GDP e.g. is below their share in the national population, and unemployment rates are significantly higher (Table 2).

The poor performance of Berlin-even though it is the biggest German agglo-

Table 2. Population, GDP and unemployment rate of the German partner regions in 2007

\begin{tabular}{|l|r|r|r|r|r|r|}
\hline & $\begin{array}{c}\text { Population } \\
\text { in million } \\
\text { inhabitants }\end{array}$ & $\begin{array}{c}\text { Proportion } \\
\text { of German } \\
\text { population } \\
\text { in \% }\end{array}$ & $\begin{array}{c}\text { GDP in } \\
\text { current } \\
\text { prices in } \\
\text { billion } \\
\text { Euro }\end{array}$ & $\begin{array}{c}\text { Proportion } \\
\text { of German } \\
\text { GDP in } \\
\text { current } \\
\text { prices in \% }\end{array}$ & $\begin{array}{c}\text { Unem- } \\
\text { ployment } \\
\text { rate in \% }\end{array}$ & $\begin{array}{c}\text { Deviation of } \\
\text { German average } \\
\text { unemployment } \\
\text { rate in percen- } \\
\text { tage points }\end{array}$ \\
\hline $\begin{array}{l}\text { Berlin- } \\
\text {-Brandenburg }\end{array}$ & 5.96 & 7.3 & 137.93 & 5.7 & 17.3 & +8.3 \\
\hline $\begin{array}{l}\text { Mecklenburg- } \\
\text {-Cispomerania }\end{array}$ & 1.68 & 2.0 & 34.78 & 1.4 & 18.1 & +9.1 \\
\hline Saxony & 4.22 & 5.1 & 92.75 & 3.8 & 16.4 & +7.4 \\
\hline $\begin{array}{l}\text { German partners } \\
\text { in Oder Partnership }\end{array}$ & 11.86 & 14.4 & 265.46 & 11.0 & 16.9 & +7.9 \\
\hline Germany & 82.22 & 100.0 & $2,422.9$ & 100.0 & 9.0 & 0.0 \\
\hline
\end{tabular}

Source: Federal Statistic Office Wiesbaden.

meration and the nation's capital-is due to the post-war history. With most financial and industrial functions having been relocated to West German cities in the immediate after-war period, industrial production in West Berlin was kept alive only by high subventions from the West German government, who also provided for a high city infrastructure level. After reunification, these subventions were quickly abolished, but the socioeconomic restructuring process of Berlin did not lead to the hoped-for "re-emergence" of the powerful capital (Tölle 2003) -in particular as the return of 
government offices remains incomplete until today. Instead Berlin became characterised in the 1990s by a failing economic restructuring process (Kujath 2005), deindustrialisation, increasing urban poorness, a still existing mental and socioeconomic East-West divide, and moreover a dramatic situation of the city's budget. Positive impulses for the Capital Region's economy are based on sectors like biotechnology and pharmaceutical industries, transportation and logistical technology and vehicle manufacturing, environmental and energy production technology, and notably creative, media and culture industries. In turn Mecklenburg-Cispomerania, whose main economic sectors are food industries, agriculture, sea industries, and tourism notably along the Baltic Sea, has been shaken after the German reunification by the deindustrialisation process of its production centres as well as the restructuring process of agriculture (including the liquidation of the former agricultural production cooperatives). This led to a difficult economic situation and to population shrinking processes in nearly all regions. In contrast, Saxony, even though there are shrinking processes and high unemployment rates, managed to keep a significant production basis and constitutes today the economically strongest region in eastern Germany. Its economic backbone is based e.g. on car manufacturing and micro technology in its urban agglomerations, while there are also structurally weak areas in northern state parts as well as booming tourism destinations in the mountainous southern parts.

In contrast, the situation of the Polish partner regions in the Oder Partnership is quite different on the national level. Except for West Pomerania unemployment rates are equal to the national average or lower. The share in the national GDP is higher than the share in population in Greater Poland and Lower Silesia, while narrowly lower in Lubusz and West Pomerania (Table 3).

Table 3. Population, GDP and unemployment rate of the Polish partner regions in 2007*

\begin{tabular}{|l|r|r|r|r|r|r|}
\hline & $\begin{array}{c}\text { Population } \\
\text { in million } \\
\text { inhabitants }\end{array}$ & $\begin{array}{c}\text { Proportion } \\
\text { of Polish } \\
\text { population } \\
\text { in \% }\end{array}$ & $\begin{array}{c}\text { GDP in } \\
\text { current } \\
\text { prices in } \\
\text { billion Euro }\end{array}$ & $\begin{array}{c}\text { Proportion } \\
\text { of Polish } \\
\text { GDP in } \\
\text { current } \\
\text { prices in } \%\end{array}$ & $\begin{array}{c}\text { Unem- } \\
\text { ployment } \\
\text { rate in \% }\end{array}$ & $\begin{array}{c}\text { Deviation of } \\
\text { Polish average } \\
\text { unemployment } \\
\text { rate in percen- } \\
\text { tage points }\end{array}$ \\
\hline $\begin{array}{l}\text { West } \\
\text { Pomerania }\end{array}$ & 1.69 & 4.4 & 11.29 & 4.1 & 16.6 & +5.2 \\
\hline Lubusz & 1.01 & 2.7 & 6.56 & 2.4 & 14.2 & +2.8 \\
\hline $\begin{array}{l}\text { Greater } \\
\text { Poland }\end{array}$ & 3.39 & 8.9 & 26.00 & 9.3 & 8.0 & -3.4 \\
\hline $\begin{array}{l}\text { Lower } \\
\text { Silesia }\end{array}$ & 2.88 & 7.6 & 22.57 & 8.1 & 11.8 & +0.4 \\
\hline $\begin{array}{l}\text { Polish part- } \\
\text { ners in Oder } \\
\text { Partnership }\end{array}$ & 8.97 & 23.5 & 66.42 & 23.8 & 11.5 & +0.1 \\
\hline Poland & 38.12 & 100.0 & 278.96 & 100.0 & 11.4 & 0.0 \\
\hline
\end{tabular}

Source: Central Statistic Office Warsaw, exchange key Euro-PLN: 1:3.8.

* GDP of 2006. 
The figures represent the West Pomeranian and Lubusz voivodship as regions characterised by agricultural functions-and tourist centres along the West Pomeranian coast line-with few urban economic centres. The West Pomeranian capital of Szczecin is together with nearby Świnoujście a Polish centre of port and sea-related service and production activities, yet is suffering under the restructuring processes in this sector, notably in ship production. In turn both capital cities of the Lubusz voivodship managed to keep a significant production structure, in Gorzów based on automotive and mechanical engineering as well as chemical and pharmaceutical industry, and in Zielona Góra on railway vehicle manufacturing, spirits production and media technology. Greater Poland and Lower Silesia-despite severe restructuring processes-have remained regions with a strong industrial production sector. The main economic pillars of Greater Poland are vehicle construction, mechanical engineering and electrical industry as well as furniture and food production. Today's leading industry sectors in Lower Silesia include electrical machinery and electronics, vehicle construction, and chemical and food-processing industries, with the traditional industries including coal, copper ore and mineral resources mining and the production of clothes, fabrics and china declining.

Hence from the respective national perspective, the four Polish partner regions have a better standing in the national hierarchy than the three German ones in their. This fact however is not to divert attention from the existing economic gap between the German and the Polish partners in the Oder partnership, with the total of the GDP of all Polish partner regions amounting to no more than one quarter of those of the German partners. From a European perspective in turn, all partners of the Oder Partnership are belonging to the weaker European regions. With regard e.g. to the GDP per capita on both sides, with 75.5 to $87.7 \%$ of the EU-27 average in 2006 all German partner regions-with the exception of Berlin -are well below the average, while the situation on the Polish side is even more dramatic: the regions' GDP per capita is around half of the EU average.

While strategic networks always try to connect differently structured partners as they are focusing on the existing strengths of all partners, the imbalances between the Oder Partnership regions certainly are to be judged as a challenge. An important difference to other transnational cooperation spaces is the lack of a metropoli$\tan$ region that constitutes an economic hub in the European context. While e.g. the Greater Region SaarLorLux has Luxembourg, the Oresund Region Copenhagen or the CENTROPE Region Vienna, the economic potential of Berlin for the Oder Partnership is much smaller, and its positioning in the partnership will need a more sophisticated approach. While being in absolute terms the biggest partner due to its size and therefore automatically raising concerns about the danger of dominating the Partnership, it is much more reliant on functioning strategic partnerships in order to raise its position on the European map of economic centres. 


\section{COOPERATION IN THE ODER PARTNERSHIP}

The Oder Partnership is to put transnational cooperation into a new dimension. While the experiences in that field of Berlin and of the Greater Poland voivodshipwith no direct foreign state border-are limited, the other partner regions have a record of cross-border cooperation notably on the level of twin city and Euroregion projects. For the 2007-2013 funding period, there are three operational programmes (i.e. "West Pomerania - Mecklenburg-Cispomerania \& Brandenburg", "Poland (Lubusz) - Brandenburg", and "Poland - Saxony") covering the closer GermanPoland borderland area (INTERREG A). Farther than that are going experiences between Lower Silesia and Saxony in form of the German-Polish-Czech border town net "Small Triangle" between Zittau, Bogatynia and Hrádek nad Nisou, andnotably interesting in the context of the Oder Partnership-concerning networking in a larger cooperation space. The latter was started in the cause of the Enlarge-Net project, which included the Dresden and Chemnitz regions and the Lower Silesia voivodship, as well as regions in the Czech Republic. This project however rather failed to produce lasting cooperation structures (Knippschild 2008).

The Oder Partnership network will need to put existing cross-border initiatives into an overarching context as existing for other partnerships e.g. in form of the "Vision CENTROPE 2015" or of the "Vision 2020" for the Greater Region SaarLorLux. The latter managed to adopt one operational programme for its cross-border projects for the 2007-2013 period under the very title of "Greater Region", thus replacing the three separate programmes of previous years. A similar programme in its own right exists for the Oresund Region (i.e. as a sub-programme) and is planned for the CENTROPE region for the next funding period. An important handicap for the Oder Partnership is however the fact that with the exception of Szczecin none of the metropolitan centres may be included in such an operational programme asother than e.g. Vienna, Luxembourg or Copenhagen in their respective region-they are to distant from the closer border area. The definition of objectives for the Oder Partnership area as a whole is necessary to shape the profile of the strategic network, to promote the partnership area, and also to enable a targeted use of European funding opportunities. The elaboration of a joint document of this kind will be a key venture for the future progress of the Oder Partnership, and the "Oder Partnership Brainstorming Workshop" in 2008 has set a foundation stone in that context.

The still few cooperation ventures started in the first three years of the Oder Partnership are a result of the practical work done in "network rounds" on the three main topics of innovation, technology and SME (coordinated by the Berlin Senate for Economics), tourism (coordinated by the Brandenburg Ministry for Economics), and transport (coordinated by the Public Transport Association of Berlin and Brandenburg). In the first field the "flagship" project so far is the JOSEFIN project which aims at creating network structures for SME in all partner regions of the Oder Partnership (with the exception of Saxony) as well as in the Baltic states, Sweden 
and Norway. Based on its predecessor TEICO-Net, it aims at opening up finance opportunities for transnational SME cooperation including coaching of enterprises and the creation of appropriate financing products. Another key product is the bilingual German-Polish internet platform EUNOP (EU-Net Oder Partnership). As a contact board, it offers information for German and Polish SME as well as research and economic institutions about non-profit institutions specialised in EU institutional and funding matters in the partner regions (again without Saxony). So far, however the involvement of the research and development sector, in the sense of creating a community of science and technology, is weak. When looking at ventures such as the "Oresund University" or the "Greenhouse Oresund" incubator one realises the potential notably of this cooperation field.

In the field of transport and logistics the regular "round table" talks inaugurated in 2006 helped to enhance cross-border rail connections by better coordination of timetables and acknowledgement of special ticket offers. They also led to common lobbying strategies with the aim to improve connections notably between Berlin and Szczecin as well as Wrocław, and to integrate Berlin into the planned Polish highspeed train network. In addition, the German side seeks to integrate its new airport Berlin Brandenburg International currently under construction into a transborder transport concept. Of importance for the cooperation area is the "Via Regia Plus" project, the follow-up of the "Via Regia" project. This venture unites more than twenty partners from Germany, Poland, the Czech Republic, Slovakia, and Ukraineincluding partners of the Oder Partnership-and aims at an integrated development of the rural and metropolitan regions in its defined corridor space. In that it puts an impetus not only on spatial and transport but also on tourism development, a point so far weak established in the Oder Partnership.

\section{CONCLUSION}

Three years after its inauguration, the Oder Partnership is still at an early stage. While there is a stable basis on the political level with annual high-level meetings it appears that tangible impulses are rather rare. However, these meetings have formed a cooperation area for networking in the sense of a "creative space", thus offering opportunities and contacts for the participating partners. First steps concerning the support of SME, the improvement of infrastructure, and the exchange of knowledge and experiences have been taken, and EU funding opportunities have played a supportive role (Kohlisch 2008). There are obvious potentials that these steps may lead to the creation of stable network structures and subsequently to cooperation structures. However, there are also threats: the different competencies of federal states in Germany in comparison to voivodships in Poland disadvantage the latter, as they are more dependent upon the central government level. This may explain, while so far most initiatives have been started by the German side, and with 
the efficiency of networks as social infrastructure being highly dependent upon personal relations between its actors the frequent change of contact persons, e.g. on a massive scale after the regional elections in Poland in 2006, poses a problem. Moreover so far on neither side has emerged a political leader who would lift the issue of transnational cooperation high on the public agenda-a crucial success factor in other cooperation spaces. There are also disproportions of engagement on both sides, notably the lacking integration of the major German cities, while all voivodships' capitals have become partners. The network as an informal tool of developing a-from a European perspective-deprived and economically backward cooperation space and transforming it in the long run into a competitive region on a global scale will need to proof its efficiency. It remains to be seen whether this tool will lead to the creation of stable and perhaps institutionalised cooperation structures.

\section{REFERENCES}

Ahlke, B., Göddecke-Stellmann, J., Illés, I., Schön, K. P. (1999), Regionen und regionale Zusammenarbeit in Europa, Informationen zur Raumentwicklung, 9-10, 687-710.

Antalovsky, E. (2006), CENTROPE_Europa Region Mitte. Eine Region mit bemerkenswerten Stärken, in: Kleger H., Lomsky A., Weigt F. (eds.), Von der Agglomeration zur Städteregion. Neue politische Denk- und Kooperationsräume, Lit Verlag, Berlin, 265-287

Castells, M. (1989), The informational city. Information technology, economic restructuring and the urban-regional process, Oxford and Cambridge (USA), Blackwell.

Ciok, S., Dołzbłasz, S., Leśniak, M., Raczyk, A. (2008), Polska-Niemcy. Wspótpraca $i$ konkurencja na pograniczu, Wydawnictwo Uniwersytetu Wrocławskiego, Wrocław.

Dühr, S., Stead, D., Zonneveld, W. (2007), The europeanization of spatial planning through territorial cooperation, Planning, Practice and Research, 22 (3), 291-307.

Fürst, D. (2005), Netzwerke, in: Akademie für Raumforschung und Landesplanung (ed.), Handwörterbuch der Raumordnung, Verlag der ARL, Hannover, 710-712.

Kaczmarek, T. (2006), Transborder co-operation and inter-territorial partnership of Polish communes and regions, Quaestiones Geographicae, 25B, 61-71.

Knieling, J., Kunzmann, K.-R. (2005), Räumliche und funktionale Netze, in: Akademie für Raumforschung und Landesplanung (ed.), Handwörterbuch der Raumordnung, Verlag der ARL, Hannover, 704-709.

Knippschild, R. (2008), Grenzüberschreitende Kooperation: Gestaltung und Management von Kooperationsprozessen in der Raumentwicklung im deutsch-polnischtschechischen Grenzraum, Leibniz Institute of Ecological and Regional Development, Dresden.

Kohlisch, T. (2008), Regional Governance in europäischen Regionen: Eine empirische Analyse der transnationalen Verbünde Großregion / La Grande Région und OderPartnerschaft / Partnerstwo Odra, Lit Verlag, Münster. 
Kujath, H. J. (2005), Restructuring of the Metropolitan Region of Berlin-Brandenburg: Economic Trends and Political Answers, Geographia Polonica, 78 (1), 117-136.

Kujath, H. J., von Schlippenbach, U. (2002), Europäische Verflechtungen deutscher Metropolregionen als Herausforderung für Politik und Wirtschaft [European linkages of German metropolitan regions as a challenge for politics and economy], Informationen zur Raumentwicklung, 6-7, 381-392.

Mission Opérationnelle Transfrontalière MOT (2006), Bonnes pratiques de gouvernance dans les agglomérations transfrontalières en Europe, MOT, Paris.

Morgan, B., Brooksbank, D., Connolly, M. (2000), The Role of Networking in the New Political Economy of Regional Development, European Planning Studies, 8 (3), 319-336.

Payer, H. (2008), Netzwerk, Kooperation, Organisation-Gemeinsamkeiten und Unterschiede, in: Bauer-Wolf, S., Payer, H. Scheer, G. (eds.), Erfolgreich durch Netzwerkkompetenz, Handbuch für Regionalentwicklung, Springer, Wien and New York, 5-22.

Stryjakiewicz, T. (2008), Spatial diversity and new conditions for regional development in Poland, in: Tarajkowski, J. and Wojtasiewicz, L. (eds.), The space in economic policy, PTPN, Poznań, 79-96.

Tölle, A. (2003), Berlin—środkowoeuropejska metropolia o granicznym położeniu, in: Breysach B., Paszek A., Tölle A. (eds.), Grenze-Granica. Prace interdyscyplinarne o podobieństwach, barierach $i$ horyzontach myślowych z perspektywy polskoniemieckiej, Logos, Berlin, 200-210. 